\title{
Persistent Post-Operative Low Back Pain, True Radiculopathy and Pseudoradiculopathy: Retrospective Observational Study and Point of View of a Practicing Clinician
}

\author{
Reynaldo P. Lazaro (1) \\ Neurology and Electroneuromyography Clinic, Oneonta, NY, USA \\ Email: RPL528@cs.com
}

How to cite this paper: Lazaro, R.P. (2021) Persistent Post-Operative Low Back Pain, True Radiculopathy and Pseudoradiculopathy: Retrospective Observational Study and Point of View of a Practicing Clinician. Open Journal of Orthopedics, 11, 289-300. https://doi.org/10.4236/ojo.2021.1110027

Received: September 7, 2021

Accepted: October 11, 2021

Published: October 14, 2021

Copyright $\odot 2021$ by author(s) and Scientific Research Publishing Inc. This work is licensed under the Creative Commons Attribution International License (CC BY 4.0).

http://creativecommons.org/licenses/by/4.0/ (c) (i) Open Access

\begin{abstract}
Purpose: Persistent Postoperative Low Back Pain (PLBP) is inordinately common, and has been attributed to various pre-operative and post-operative anatomical and mechanical factors in the spine. It may or may not be associated with sensory symptoms in the lower extremities-frequently termed "radiculopathy" - with or without Electromyographic (EMG) or imaging abnormalities. The present study aimed to look at these various symptoms in the lower extremities from a different angle and perspective and to clarify the distinction between true radiculopathy and pseudoradiculopathy; and determine their possible relationship with the outcome of surgery. Methods: Medical records of twenty-four patients with PLBP who were referred to the author for clinical and electrodiagnostic examinations several months after surgery were reviewed. Clinical symptomatology, with special reference to the presence or absence of sensory and motor deficits together with EMG findings, were reviewed and categorized into 4 groups: non radicular, true radiculopathy, pseudoradiculopathy, and peripheral neuropathy. Results: Lower Back Pain (LBP) in all patients persisted following successful and uncomplicated surgery. LBP in patients with true radiculopathy persisted but was less disabling when the neurologic deficits resolved partially or significantly. As expected, the neurologic deficits related to peripheral neuropathy, together with LBP, remained persistent. Conclusion: LBP and various sensory and motor symptoms in the lower extremities are 2 distinct entities, both clinically and pathophysiologically. These sensory and motor symptoms, together with the heightened activity of various pro-inflammatory cytokines and neurotrophins-setting aside the various anatomical and mechanical factors in the spine-can influence the outcome of surgery, favorably or unfavorably.
\end{abstract}




\section{Keywords}

Radiculopathy, Complex Regional Pain, Low Back Pain, Sinuvertebral Nerve, Cytokines, Neurotrophins

\section{Introduction}

Multiple factors have been implicated in persistent Postoperative Low Back Pain (PLBP). These factors include failure to decompress a compromised nerve root due to a herniated disc or foraminal stenosis, recurrent disc herniation, persistent instability of the painful joint, presence of multiple degenerative disc disease, the unsuccessful fusion of 2 vertebra, implant failure, infections, and epidural scarring and fibrosis [1]-[8]. Ramifications of PLBP include mental anguish, depression and anxiety, analgesic abuse and drug addiction, economic losses for patients and health insurance providers, and legal and occupational hassles for the pain sufferers [9]. Concurrent conditions such as diabetes, obesity, smoking, peripheral vascular disease, and systemic disorders complicate matters. Indifference and lack of compassion and negative attitudes among some health care providers towards LBP sufferers, add to the psychosocial miseries of these patients.

Identification of the generator of LBP is of paramount importance [10] [11], but it is not straightforward. LBP can be axial or mechanical, and is either diffuse or localized [11] [12] [13] [14]. When associated with spinal nerve root impingement, loss of muscle stretch reflexes, dermatomal sensory loss and focal muscle weakness, invariably occur (true radiculopathy). When pain extends to the lower extremity, it is termed "radicular pain", and it can occur without clear sensory loss or muscle weakness. This pain is mediated by the dorsal root ganglion [15] [16]. LBP pain can be generated from the outer layers of the annulus fibrosus of the intervertebral discs, the ventral surface of the dura mater, the periosteum of the spinal canal, and the posterior longitudinal ligaments, all of which receive innervations from the Sinuvertebral Nerve (SVN). The SVN, or recurrent nerve of Luschka, originates from the ventral ramus and re-enters the spinal canal via the intervertebral foramina to innervate the above structures, including the local blood vessels [10] [15] [17] [18] [19] [20] [21]. The SVN communicates with the sympathetic nerve trunk which may explain why some patients may experience cold sensation or vasomotor symptoms in the affected extremity in addition to various sensory symptoms (paresthesias) without focal neurologic deficits (pseudoradiculopathy). Despite this anatomical relationship, the incidence of complex regional pain syndrome-a condition characterized by vasomotor symptoms in the affected limb and allodynia-in LBP with or without radiculopathy, is unknown at this time.

In this study, we aimed to offer alternative explanations to PLBP from the clinical standpoint, to discuss the distinction between true radiculopathy and 
pseudoradiculopathy and their relation with axial pain, and to determine the type of clinical symptomatology that may be associated with the risk for developing PLBP. Cases involving the well-recognized causal factors implicated in PLBP were excluded from this study, hence the reason for not using the term Failed Lower Back Surgery Syndrome (FLBS). We feel that the present observational study could pave the way to a better understanding of the phenomenology of PLBP, by paying close attention to clinical symptomatology and/or EMG findings, and how they can potentially influence the outcome of surgery. The impetus that drove us to report our clinical observation was our experience with a number of patients we have evaluated in the past years with Herniated Discs (HD), LBP and various "radicular" symptoms, who declined to undergo surgery, but whose symptoms modestly and significantly improved utilizing conservative therapy-including spontaneous regression of HD in some cases, a phenomenon that has been documented radiologically in previous studies [22] [23] [24] [25]. Although the number of patients in this study was small, we felt nonetheless compelled to report our observation and formulate a unifying and alternative approach to the treatment of LBP.

\section{Materials and Methods}

The pattern of pre-operative and post-operative clinical symptoms and neurological deficits of 24 patients (17 males, 7 females; age range 26 - 58) were reviewed retrospectively by the author (board-certified neurologist and board-certified electromyographer), analyzed and grouped into 4 categories. These patients were referred for electrodiagnostic examination and/or neurological evaluation by various health care practitioners, 3 - 6 months following successful and uncomplicated surgery, and were selected from a large number of PLBP referred to our clinic during a 30-year period. They were followed up for 3 - 5 years following the initial evaluation. None of the patients developed surgical complications or metal hardware failure. Those with history of previous lumbar spine surgery, active systemic, metabolic and connective tissue disorders, poorly controlled diabetes, gastrointestinal and renal diseases, osteoporosis, malignancy, chronic infection, fibromyalgia, pre-existing spinal deformities, and chronic psychiatric disorders, and those with question of metal hardware issues were excluded. Epidural injections were administered to 10 patients prior to surgery with modest to significant but temporary pain relief. All had significant one-level disc herniation and various degrees of disc bulging or degenerating discs and mild osteoarthritis without significant spinal or foraminal stenosis. All underwent discectomy and spinal fusion, using either autograft or allograft, without peri-operative or postoperative complications. All retained the metal hardware placed during the surgery without instability demonstrated in subsequent radiographic studies. Four patients (Group 4) with concurrent Peripheral Neuropathy (PN) discovered during electrodiagnostic examinations were included. None underwent chiropractic therapy. 
Antecedent events identified were job-related injuries in 17 cases, and vehicular accidents in 3. No clear proximate cause of the LBP was identified in 4 cases. Medical-legal issues were resolved at the time of clinical and electrodiagnostic evaluations. A summary of occupational and sociodemographic data is illustrated in Table 1.

The clinical symptomatology, presence or absence of neurologic deficits, and EMG abnormalities were categorized into 4 groups (Table 2): Group 1 (non-radicular), characterized by LBP extending unilaterally or bilaterally to the buttock and hip with normal neurological examination and EMG studies (5 patients); Group 2 (true radiculopathy), characterized by LBP with radicular and neurological deficits and abnormal EMG (6 patients: two L3, one L4, two L5, and one

Table 1. Summary of occupational and sociodemographic data.

\begin{tabular}{|c|c|c|c|c|}
\hline & $\begin{array}{l}\text { Group } 1(\mathrm{n}=5) \\
\text { (nonradicular) }\end{array}$ & $\begin{array}{c}\text { Group } 2(\mathrm{n}=6) \\
\text { (true radiculopathy) }\end{array}$ & $\begin{array}{l}\text { Group } 3(\mathrm{n}=9) \\
\text { (pseudoradiculopathy) }\end{array}$ & $\begin{array}{c}\text { Group } 4(\mathrm{n}=4) \\
\text { (peripheral } \\
\text { neuropathy) }\end{array}$ \\
\hline $\begin{array}{l}\text { Social/economic } \\
\text { status }\end{array}$ & $\begin{array}{l}\text { Working } \\
\text { middle class }\end{array}$ & $\begin{array}{l}\text { Working } \\
\text { middle class }\end{array}$ & $\begin{array}{l}\text { Working } \\
\text { middle class }\end{array}$ & $\begin{array}{l}\text { Working } \\
\text { middle class }\end{array}$ \\
\hline $\begin{array}{l}\text { Ethnic } \\
\text { composition } \\
\text { \& age range }\end{array}$ & $\begin{array}{l}\text { White Caucasian, } \\
36 \text { - } 55 \text { years }\end{array}$ & $\begin{array}{c}\text { White Caucasian, } \\
28 \text { - } 31 \text { years }\end{array}$ & $\begin{array}{l}\text { White Caucasian, } \\
26 \text { - } 58 \text { years }\end{array}$ & $\begin{array}{l}\text { White } \\
\text { Caucasian, } \\
30 \text { - } 50 \text { years }\end{array}$ \\
\hline $\begin{array}{l}\text { Occupational } \\
\text { backgrounds } \\
\text { represented }\end{array}$ & $\begin{array}{l}\text { Construction, } \\
\text { retail/grocery }\end{array}$ & $\begin{array}{l}\text { Healthcare, } \\
\text { office/clerical }\end{array}$ & $\begin{array}{l}\text { Construction, } \\
\text { retail/grocery }\end{array}$ & $\begin{array}{c}\text { Sales, } \\
\text { office work }\end{array}$ \\
\hline
\end{tabular}

Table 2. Summary of clinical, EMG and MRI findings.

\begin{tabular}{|c|c|c|c|c|}
\hline & $\begin{array}{c}\text { Group } 1(\mathrm{n}=5) \\
\text { (nonradicular) }\end{array}$ & $\begin{array}{c}\text { Group } 2(\mathrm{n}=6) \\
\text { (true radiculopathy) }\end{array}$ & $\begin{array}{c}\text { Group } 3(\mathrm{n}=9) \\
\text { (pseudoradiculopathy) }\end{array}$ & $\begin{array}{c}\text { Group } 4(\mathrm{n}=4) \\
\text { (peripheral } \\
\text { neuropathy) }\end{array}$ \\
\hline $\begin{array}{l}\text { Pattern of } \\
\text { clinical } \\
\text { symptoms } \\
\text { and deficits }\end{array}$ & $\begin{array}{l}\text { LBP extending } \\
\text { unilaterally or } \\
\text { bilaterally to } \\
\text { buttocks or hips } \\
\text { with normal } \\
\text { neuromuscular } \\
\text { examination }\end{array}$ & $\begin{array}{l}\text { LBP with unilateral } \\
\text { radicular and } \\
\text { neuromuscular } \\
\text { deficits (focal } \\
\text { myotonal weakness, } \\
\text { foot drop, and } \\
\text { absent ankle jerk) }\end{array}$ & $\begin{array}{c}\text { LBP with } \\
\text { nondermatomal } \\
\text { unilateral sensory } \\
\text { symptoms in } \\
5 \text { patients, and } \\
\text { bilateral sensory and } \\
\text { cold and swollen } \\
\text { sensation in the thighs } \\
\text { and legs in } 4 \text { patients }\end{array}$ & $\begin{array}{c}\text { LBP with } \\
\text { bilateral sensory } \\
\text { and motor deficits } \\
\text { including } \\
\text { loss of muscle } \\
\text { stretch reflexes }\end{array}$ \\
\hline $\begin{array}{l}\text { EMG nerve } \\
\text { conduction } \\
\text { findings }\end{array}$ & Normal & $\begin{array}{c}\text { Abnormal EMG; } \\
\text { normal nerve } \\
\text { conduction }\end{array}$ & Normal & $\begin{array}{l}\text { Both abnormal } \\
\text { EMG and } \\
\text { abnormal nerve } \\
\text { conduction }\end{array}$ \\
\hline $\begin{array}{c}\text { MRI } \\
\text { findings }\end{array}$ & $\begin{array}{l}\text { HNP (L3 - } 4 \text { in } \\
2 \text { patients; } \\
\text { L4 - } 5 \text { in } \\
2 \text { patients; L5 - S1 } \\
\text { in } 1 \text { patient); } \\
\text { bulging and disc } \\
\text { degeneration }\end{array}$ & $\begin{array}{c}\text { HNP (L2 - } 3 \text { in } \\
2 \text { patients; L3 - } 4 \text { in } \\
1 \text { patient; L4 - } 5 \text { in } \\
2 \text { patients; L5 - S1 in } \\
1 \text { patient); } \\
\text { bulging and disc } \\
\text { degeneration }\end{array}$ & $\begin{array}{c}\text { HNP (L4 - } 5 \text { in } 5 \\
\text { patients and L5 - S1 } \\
\text { in } 4 \text { patients); bulging } \\
\text { and mild disc } \\
\text { degeneration }\end{array}$ & $\begin{array}{l}\text { HNP (L3 - } 4 \text { in } \\
1 \text { patient and } \\
\text { L4 - } 5 \text { in } 2 \\
\text { patients); bulging } \\
\text { and mild disc } \\
\text { degeneration } \\
\text { in } 1 \text { patient }\end{array}$ \\
\hline
\end{tabular}

Notes: Abbreviations: HNP, herniated nucleus pulposus; LBP, lower back pain. 
S1); Group 3 (pseudoradiculopathy), characterized by LBP with nondermatomal, unilateral sensory symptoms extending diffusely to the foot without focal neurological deficits and with normal EMG (5 patients, four of whom had bilateral, nondermatomal sensory and vasomotor (cold and swollen sensation) in the thighs and legs and normal EMG); and Group 4 (peripheral neuropathy), characterized by LBP with bilateral glove-stocking sensory symptoms and bilateral distal muscle weakness and atrophy, along with loss of muscle stretch reflexes (4 patients). These patients, with no prior pre-operative electrodiagnostic examination, had abnormal peripheral nerve conduction examination consistent with peripheral sensory and motor polyneuropathy (1 idiopathic axonal sensory polyneuropathy, $3 \mathrm{ch}$ ronic demyelinating and axonal polyneuropathy).

Over the course of 30 years, various EMG-NCV machines (TECA TD 10 and Sapphire, Nicolet Viking EMG-EP, and Cadwell Sierra II Wedge EMG-NCV systems) were used in this study.

\section{Results}

With the exception of those in Group 2, all patients had persistent and disabling PLBP following surgery. Those in group 2 had gradual and partial resolution of neurological deficits, particularly weakness of the quadriceps and adductor muscles (L3), ankle dorsiflexors (L5), and plantar flexors (S1). However, the patients in this group continued to suffer from lingering but tolerable LBP. The PLBP in group 4 was overshadowed by the sensory and motor deficits related to PN, but both were equally disabling.

EMG was normal in all patients in Groups 1 and 3. All patients in Group 2, who had abnormal pre-operative EMG, had mild post-operative abnormalities, which consisted of sharp positive waves, occasional fibrillation potentials and signs of chronic denervation-reinnervation (complex and high-amplitude motor units). All EMGs (including peripheral nerve conduction studies in Group 4) were abnormal and consistent with peripheral polyneuropathy.

All patients particularly construction workers were unable to return to their original line of work. Young health care workers were able to return to work but only on a sedentary or part-time basis. Additional imaging studies showed mild progression of various degenerative changes demonstrated previously.

\section{Discussion}

In general, LBP (or neck pain) and radiculopathy (lumbar or cervical) are 2 separate entities, clinically and pathophysiologically [14] [16] [26]. However, more often than not, they are likely to occur together following spinal injuries (Group 2). Disc herniation can be viewed as collateral damage after an injury, but it becomes clinically significant when it impinges on a nerve root or cauda equina. Depending on the nature and severity of an injury and resultant disruption to spine anatomy, LBP can be more prominent than radiculopathy or vice versa. Pain resulting from disc displacement or desiccation is influenced by changes in 
body position, especially bending or prolonged sitting, which increase intradiscal pressure (mechanical or axial pain, Group 1). The signs and symptoms resulting from spinal nerve root compromise are very easily recognizable in a clinical setting, even without the use of electrodiagnostic procedures-particularly EMG [27] [28] [29]. It is noteworthy that radicular deficits may occur with very little or no LBP [14]. There are times, however, when the sensory symptoms in the lower extremities do not have typical dermatomal distribution and are not associated with motor deficits. Regardless, these sensory symptoms in the lower extremities are often and loosely interpreted as radiculopathy (5 patients in Group 3). The term "pseudoradiculopathy" was used to describe this group of patients.

One particular and intriguing constellation of symptoms that is not well recognized and is frequently overlooked in LBP, consists of cold and swollen sensations in the lower extremity, at times associated with reddish discoloration of the skin. They are termed vasomotor symptoms (4 patients in Group 3), and are unilateral or bilateral, intermittent or steady, and without dermatomal distribution. These symptoms are sometimes experienced by patients with severe axial back pain, and are accompanied by preserved sensory perception and preserved reflexes and muscle tone. It can occur regardless of body position. This change in temperature perception is likely generated by the sympathetic nerve components of the SVN [18] [30]. The symptom is usually evident clinically but can be documented objectively using thermal imaging, which was not performed in this study. At times, it is masked by the presence of neurologic deficits due to nerve root compromise.

Clinical categorization of low back pain syndrome may have practical therapeutic and prognostic implications. In Group 2 patients, where sensory and motor deficits were out of proportion to LBP, surgical success was predictable, especially when associated with clear radiological and EMG abnormalities. The high success rate is analogous to carpal tunnel syndrome when the symptoms are primarily related to median nerve compression, and not to musculotendinous and ligamentous irritation in the wrists and hands [31]. In both situations, decompression of the affected spinal nerve root (or the median nerve) will result in resolution of symptoms related to the nerve trunk irritation but not those related to irritation of the small-diameter pain fibers innervating the tissues in the musculoskeletal compartment and joints.

It appears that when LBP is the primary and most disabling symptom (Groups 1 and 3, without neurologic deficits or with vasomotor symptoms in the lower extremities), PLBP seems likely to occur. This clinical presentation, especially in the presence of concurrent disc desiccations, and poor surgical outcome, requires further elucidation. Unlike a clearly demonstrable focal lesion as in true radiculopathy, LBP is invariably diffuse and non-localizing because the SVN innervation has multi-segmental levels of overlap and, together with its sympathetic nerve component, makes LBP a combination of somatic and visceral pain [30]. Such a unique anatomical system may contribute to the variable outcome of 
surgery. The intervertebral disc is poorly innervated, supplied only by nociceptive and postganglionic sympathetic nerve fibers. However, during degenerative processes, the disc becomes densely innervated, and worsens the pre-existing LBP in this condition [32]. This pain is mediated by molecules of some members of neurotrophins which regulate the density and distribution of nerve fibers in the peripheral tissues. They are a family of proteins belonging to a class of growth factors that send signals to neural tissues to grow or differentiate, and play a role in inflammatory process and pain transmission [32] [33] [34]. As a result of the multi-segmental level of SVN innervation, and during the process of reinnervation, LBP becomes poorly localized. This can be compounded by concurrent facet inflammation that can sensitize the local mechanoreceptors into becoming pain afferents, resulting in discogenic pain [11] [17].

Although highly speculative, that some cases of PLBP may be a form of proximal Complex Regional Pain Syndrome (CRPS), is a possibility worthy of consideration. This is a "self perpetuating" chronic pain that usually affects the distal segments of the upper or lower extremities, and is characterized by allodynia (hypersensitive skin) and symptoms of sympathetic nerve dysfunction (cold or warm sensations), focal sweating and swelling and skin discoloration and, in some instances, trophic changes affecting the integument and joints of the affected extremity. This possibility may not necessarily be far-fetched considering that LBP is, pathophysiologically speaking, mediated by the SVN, a nerve that is both autonomic (sympathetic) and somatic. Health care providers who take care of patients with LBP are familiar with the presence of allodynia in the lower back, which may sometimes be construed as symptom augmentation or malingering. Although the innate cytokine profile in patients in CRPS is normal [35], the elevated blood levels of inflammatory monocytes along with the shift towards a pro-inflammatory cytokine profile in patients with this condition would suggest a potential role of the immune system in the pathogenesis of chronic pain [36] [37], including LBP. For this matter, when the nucleus pulposus-an avascular and an immune-privileged fibrocartilagenous organ in the human body- becomes extruded into the epidural space, a cascade of autoimmune reactions develop. These reactions involve activation of the macrophages and monocytes to initiate the resorption of the herniated disc [38]. However, whether such a process has any effect on LBP or on radicular deficits is another issue that requires further study.

When sensory symptoms and motor deficits affect the lower extremities bilaterally, concurrent peripheral nerve disease masked by the LBP can lead to diagnostic confusion, especially when the patient's history shows absence of systemic or toxic/metabolic disorders-such as connective tissue diseases, systemic infections, and diabetes, to name a few-that can affect the peripheral nerves (Group 4). In this situation, health care providers can be lulled into complacency thinking that these neurologic deficits all originate from the spinal column. Moreover, the presence of concurrent peripheral nerve disorder can create medical and le- 
gal controversies, especially when patients bring up a causal relationship between a traumatic disc disease and peripheral neuropathy. Although this causality is not scientifically valid, such an issue can pose a confusing situation on the part of injured laypersons.

Here, the value of meticulous physical and electrodiagnostic examination, particularly the clinical diagnostic acumen of the electromyographer, becomes germane.

In recent years, numerous studies have been conducted to determine the role of pro-inflammatory cytokines in acute and chronic persistent pain [28] [33] [39]-[49]. Cytokines are low molecular weight proteins secreted by cells of the immune system, and are produced during various inflammatory processes, including pain. They act as messengers between cells, and regulate the body's responses in both normal and pathologic states such as infection, malignancy, and trauma. They include families of interferons, chemokines, tumor necrosis factors, interleukins and transforming growth factor, hematopoietins, and lymphokines. They are produced by various immune cells, such as B and T lymphocytes, macrophages, mast cells, endothelial cells, fibroblasts, and stromal cells. Recent studies have shown that patients with LBP have higher levels of pro-inflammatory cytokines compared with control subjects. This is not surprising, since trauma can activate nociceptors, leading to release of inflammatory mediators such as cytokines, bradykinin, and prostaglandins. Therefore, it is theoretically and logically possible that additional trauma, including extensive tissue manipulation during surgery, may further increase the level of cytokines, and lead to perpetuation of pain. With each passing case and persistently high incidence of PLBP (or FLBS) the time has come to focus attention on the "surge" of these cytokines-and how it can be treated using bio-immunologic agents-before proceeding to the application of established surgical approaches in the treatment of LBP or PLBP, particularly in cases without associated neurologic deficits and/or active EMG abnormalities.

\section{Conclusion}

We concluded that PLBP may not necessarily be directly related to anatomical and mechanical factors frequently implicated in FLBS but may be due to disruption of the intricate, interconnecting, and complex system of pain receptors and small-diameter pain fibers originating from the sinuvertebral and sympathetic nerves, interacting in concert with various pro-inflammatory cytokines and neurotrophins. Localized LBP and LBP associated with pseudoradicular symptomsespecially when associated with vasomotor symptoms, degenerative changes, and discopathies above and below the disc herniation-may constitute risk factors for PLBP. True radiculopathy and LBP are clinically and pathophysiologically distinct; the latter may persist even after surgery. Peripheral nerve conduction study in LBP, although usually not indicated, becomes necessary when associated with bilateral and symmetrical sensory and motor deficits, even in the presence of unequivocal MRI abnormalities. 


\section{Acknowledgements}

The authors would like to thank Ms. Alice Bauer for assorting all clinical materials, EMG reports, and imaging studies of the patients described in this work. The detailed editing provided by Mr. Michael W. Lazaro and the Scribendi editing service was quite invaluable.

\section{Conflicts of Interest}

The author declares no conflicts of interest regarding the publication of this paper.

\section{References}

[1] Baber, Z. and Erdek, M.A. (2016) Failed Back Surgery Syndrome: Current Perspectives. Journal of Pain Research, 9, 979-987. https://doi.org/10.2147/JPR.S92776

[2] Bordoni, B. and Marelli, F. (2016) Failed Back Surgery Syndrome: Review and New Hypothesis. Journal of Pain Research, 9, 17-22. https://doi.org/10.2147/JPR.S96754

[3] Chou, R., Baisden, J., Carragee, E.J., Resnick, D.K., Shaffer, W.O. and Loeser, J.D. (2009) Surgery for Low Back Pain: A Review of the Evidence for an American Pain Society Clinical Practice Guideline. Spine, 34, 1094-1109. https://doi.org/10.1097/BRS.0b013e3181a105fc

[4] Cloward, R.B. (1960) The Clinical Significance of the Sinuvertebral Nerve of the Cervical Spine in Relation to the Cervical Disc Syndrome. Journal of Neurology, Neurosurgery, and Psychiatry, 23, 321-326. https://doi.org/10.1136/jnnp.23.4.321

[5] Daniell, J.R. and Osti, O.L. (2018) Failed Back Surgery Syndrome: A Review Article. Asian Spine Journal, 12, 372-379. https://doi.org/10.4184/asj.2018.12.2.372

[6] Fritsch, E.W., Heisel, J. and Rupp, S. (1996) The Failed Back Surgery Syndrome: Reasons, Intraoperative Findings, and Long-Term Results: A Report of 182 Operative Treatments. Spine, 21, 626-633. https://doi.org/10.1097/00007632-199603010-00017

[7] Hoy, D., March, L., Brooks, P., Blyth, F., Woolf, A., et al. (2014) The Global Burden of Low Back Pain: Estimates from the Global Burden of Disease 2010 Study. Annals of the Rheumatic Diseases, 73, 968-974.

https://doi.org/10.1136/annrheumdis-2013-204428

[8] Reddi, D. and Curran, N. (2014) Chronic Pain after Surgery: Pathophysiology, Risk Factors and Prevention. Postgraduate Medical Journal, 90, 222-227. https://doi.org/10.1136/postgradmedj-2013-132215

[9] Gore, M., Sadosky, A., Stacey, B.R., Tai, K. and Leslie, D. (2012) The Burden of Chronic Low Back Pain: Clinical Comorbidities, Treatment Patterns, and Health Care Costs in Usual Care Settings. Spine, 37, E668-E677. https://doi.org/10.1097/BRS.0b013e318241e5de

[10] Groen, G.J., Baljet, B. and Drukker, J. (1990) Nerves and Nerve Plexuses of the Human Vertebral Column. The American Journal of Anatomy, 188, 282-296. https://doi.org/10.1002/aja.1001880307

[11] Ellenberger, C. (1994) MR Imaging of the Low Back Syndrome. Neurology, 44, 594-600. https://doi.org/10.1212/WNL.44.4.594

[12] Cavanaugh, J.M., Ozaktay, A.C., Yamashita, T., Avramov, A., Getchell, T.V. and King, A.I. (1997) Mechanisms of Low Back Pain: A Neurophysiologic Study and Neuroanatomic Study. Clinical Orthopaedics and Related Research, 335, 166-180. 
https://doi.org/10.1097/00003086-199702000-00016

[13] Hurri, K. and Karppinen, J. (2004) Discogenic Pain. Pain, 112, 225-228. https://doi.org/10.1016/j.pain.2004.08.016

[14] Nakamura, S.I., Takahashi, K., Takahashi, Y., Yamagata, M. and Moriya, H. (1996) The Afferent Pathways of Discogenic Low-Back Pain: Evaluation of L2 Spinal Nerve Infiltration. The Journal of Bone and Joint Surgery, 78, 606-612. https://doi.org/10.1302/0301-620X.78B4.0780606

[15] Bogduk, N. (1983) The Innervation of the Lumbar Spine. Spine, 8, 286-293. https://doi.org/10.1097/00007632-198304000-00009

[16] Bogduk, N. (2003) The Anatomy and Pathophysiology of Neck Pain. Physical Medicine and Rehabilitation Clinics of North America, 14, 455-472. https://doi.org/10.1016/j.pmr.2011.03.008

[17] Edgar, M.A. (2007) The Nerve Supply of the Lumbar Intervertebral Disc. The Journal of Bone and Joint Surgery, 89, 1135-1139. https://doi.org/10.1302/0301-620X.89B9.18939

[18] Raoul, S., Faure, A., Robert, R., Rogez, J., Hamel, O., et al. (2003) Role of the Sinu-Vertebral Nerve in Low Back Pain and Anatomical Basis of Therapeutic Implications. Surgery and Radiologic Anatomy, 24, 366-371. https://doi.org/10.1007/s00276-002-0084-8

[19] Rea, W., Kapur, S. and Mutagi, H. (2012) Intervertebral Disc as a Source of Pain. Continuing Education in Anaesthesia. Critical Care \& Pain, 12, 279-282.

https://doi.org/10.1093/bjaceaccp/mks028

[20] Shayota, B., Wong, T.L., Fru, D., David, G., Iwanga, J., et al. (2019) A Comprehensive Review of the Sinuvertebral Nerve with Clinical Applications. Anatomy \& Cell Biology, 52, 128-133. https://doi.org/10.5115/acb.2019.52.2.128

[21] Zhao, Q., Cheng, L., Yan, H., Deng, S., Zhao, J., et al. (2020) The Anatomical Study and Clinical Significance of the Sinuvertebral Nerves at the Lumbar Levels. Spine, 45, E61-E66. https://doi.org/10.1097/BRS.0000000000003190

[22] Chiu, C., Chuang, T., Chang, K., Wu, C., Lin, P. and Hsu, W. (2015) The Probability of Spontaneous Regression of Lumbar Herniated Disc: A Systematic Review. Clinical Rehabilitation, 29, 184-195. https://doi.org/10.1177/0269215514540919

[23] Teplick, J.G. and Haskin, M.E. (1985) Spontaneous Regression of Herniated Nucleus Pulposus. American Journal of Roentgenology, 145, 371-375. https://doi.org/10.2214/ajr.145.2.371

[24] Macki, M., Hernandez-Hermann, M., Bydon, M., Gokaslan, A., McGovern, K. and Bydon, A. (2014) Spontaneous Regression of Sequestered Lumbar Disc Herniations: Literature Review. Clinical Neurology and Neurosurgery, 120, 136-141. https://doi.org/10.1016/j.clineuro.2014.02.013

[25] Saal, J.A., Saal, J.S. and Herzog, R.J. (1990) The Natural History of Lumbar Intervertebral Disc Extrusions Treated Nonoperatively. Spine, 15, 683-686. https://doi.org/10.1097/00007632-199007000-00013

[26] Christellis, N., Simpson, B., Russo, M., Stanton-Hicks, M., Barolat, G., et al. (2021) Persistent Spinal Pain Syndrome: A Proposal for Failed Back Surgery Syndrome and ICD-11. Pain Medicine, 22, 807-818. https://doi.org/10.1093/pm/pnab015

[27] Lazaro, R.P. (2015) Electromyography in Musculoskeletal Pain: A Reappraisal and Practical Considerations. Surgical Neurology International, 6, 143-146.

https://doi.org/10.4103/2152-7806.163816

[28] Le Maitre, C.L., Hoyland, J.A. and Freemont, A.J. (2007) Catabolic Cytokine Ex- 
pression in Degenerate and Herniated Human Intervertebral Discs: IL-1 $\beta$ and TNFa Expression Profile. Arthritis Research \& Therapy, 9, Article No. R77. https://doi.org/10.1186/ar2275

[29] Madden, P.J. and Lazaro, R.P. (1997) Drooping of the Big Toe: Another Diagnostic Marker for L-5 Radiculopathy. Southern Medical Journal, 90, 209-210. https://doi.org/10.1097/00007611-199702000-00008

[30] Jinkins, J.R., Whittemore, A.R. and Bradley, W.G. (1989) The Anatomic Basis of Vertebrogenic Pain and the Autonomic Syndrome Associated with Lumbar Disc Extrusion. American Journal of Roentgenology, 152, 1277-1289.

https://doi.org/10.2214/ajr.152.6.1277

[31] Lazaro, R.P. (1997) Neuropathic Symptoms and Musculoskeletal Pain in Carpal Tunnel Syndrome: Prognostic and Therapeutic Implications. Surgical Neurology, 47, 115-119. https://doi.org/10.1016/S0090-3019(95)00457-2

[32] Garcia-Cosamalon, J., Del Valle, M.E., Calavia, M.G., Garcia-Suarez, O., Lopez-Muniz, A., et al. (2010) Intervertebral Disc, Sensory Nerves and Neurotrophins: Who Is Who in Discogenic Pain? Journal of Anatomy, 217, 1-15. https://doi.org/10.1111/j.1469-7580.2010.01227.x

[33] Freemont, A.J. (2009) The Cellular Pathobiology of the Degenerate Intervertebral Disc and Discogenic Back Pain. Rheumatology, 48, 5-10.

https://doi.org/10.1093/rheumatology/ken396

[34] Gruber, H.E., Hoelscher, G.L., Ingram, J.A. and Hanley, E.N. (2012) Genome-Wide Analysis of Pain-, Nerve- and Neurotrophin-Related Gene Expression in the Degenerating Human Annulus. Molecular Pain, 8, Article No. 63.

https://doi.org/10.1186/1744-8069-8-63

[35] Van de Beek, W.J.T., Remarque, E.J., Westendorp, R.G.J. and Van Hilten, J.J. (2001) Innate Cytokine Profile in Patients with Complex Regional Pain Syndrome Is Normal. Pain, 91, 259-261. https://doi.org/10.1016/S0304-3959(00)00443-7

[36] Ritz, B.W., Alexander, G.M., Nogusa, S., Perreault, M.J., Peterlin, B.L., et al. (2011) Elevated Levels of Inflmammatory Monocytes $\left(\mathrm{CD} 14^{+} \mathrm{CD} 16^{+}\right)$in Patients with Complex Regional Pain Syndrome. Clinical and Experimental Immunology, 164, 108-117. https://doi.org/10.1111/j.1365-2249.2010.04308.x

[37] Uceyler, N., Eberle, T., Rolke, R., Birklein, F. and Sommer, C. (2007) Differential Expression Patterns of Cytokines in Complex Regional Pain Syndrome. Pain, 132, 195-205. https://doi.org/10.1016/j.pain.2007.07.031

[38] Cunha, C., Silva, A.J., Pereira, P., Vaz, R., Goncalves, R.M. and Barbosa, M.A. (2018) The Inflammatory Response in the Regression of Lumbar Disc Herniation. Arthritis Research \& Therapy, 20, 251. https://doi.org/10.1186/s13075-018-1743-4

[39] Borish, L.C. and Steinke, J.W. (2003) Cytokines and Chemokines. The Journal of Allergy and Clinical Immunology, 111, S460-S475. https://doi.org/10.1067/mai.2003.108

[40] Brenn, D., Richter, F. and Schaible, H. (2007) Sensitization of Unmyelinated Sensory Fibers of the Joint Nerve to Mechanical Stimuli by Interleukin-6 in the Rat: An Inflammatory Mechanism of Joint Pain. Arthritis \& Rheumatism, 56, 351-359. https://doi.org/10.1002/art.22282

[41] Cuellar, J.M., Golish, S.R., Reuter, M.W., Cuellar, V.G., Angst, M.S., et al. (2010) Cytokine Evaluation in Individuals with Low Back Pain Using Discographic Lavage. The Spine Journal, 10, 212-218. https://doi.org/10.1016/j.spinee.2009.12.007

[42] Jacobsen, H.E., Khan, A.N., Levine, M.E., Filippi, C.G. and Chahine, N.O. (2020) Severity of Intervertebral Disc Herniation Regulates Cytokine and Chemokine Levels in Patients with Chronic Radicular Back Pain. Osteoarthritis and Cartilage, 28, 
1341-1350. https://doi.org/10.1016/j.joca.2020.06.009

[43] Kraychete, D.C., Sakata, R.K., Issy, A.M., Bacellar, O., Santos-Jesus, R. and Carvalho, E.M. (2010) Serum Cytokine Levels in Patients with Chronic Low Back Pain Due to Herniated Disc: Analytical Cross-Sectional Study. Sao Paulo Medical Journal, 128, 259-262. https://doi.org/10.1590/S1516-31802010000500003

[44] Risbud, M.V. and Shapiro, I.M. (2014) Role of Cytokines in Intervertebral Disc Degeneration: Pain and Disc Content. Nature Reviews. Rheumatology, 10, 44-56. https://doi.org/10.1038/nrrheum.2013.160

[45] Takahashi, H., Suguro, T., Okazima, Y., Motegi, M., Okada, Y. and Kakiuchi, T. (1996) Inflammatory Cytokines in the Herniated Disc of the Lumbar Spine. Spine, 21, 218-224. https://doi.org/10.1097/00007632-199601150-00011

[46] Weber, K.T., Alipui, D.O., Sison, C.P., Bloom, O., Quraishi, S., et al. (2016) Serum Levels of the Proinflammatory Cytokine Interleukin-6 Vary Based on Diagnoses in Individuals with Lumbar Intervertebral Disc Diseases. Arthritis Research \& Therapy, 18, Article No. 3. https://doi.org/10.1186/s13075-015-0887-8

[47] Wuertz, K. and Haglund, L. (2013) Inflammatory Mediators in Intervertebral Disk Degeneration and Discogenic pain. Global Spine Journal, 3, 175-184. https://doi.org/10.1055/s-0033-1347299

[48] Xiaogang, M., Quanshan, H., Liping, Z. and Kaken, H. (2017) The Expression of Cytokine and Its Significance for the Intervertebral Disks of Kazakhs. Journal of Clinical Laboratory Analysis, 31, e22087. https://doi.org/10.1002/jcla.22087

[49] Zhang, J.M. and An, J.X. (2007) Cytokines, Inflammation, and Pain. International Anesthesia Clinics, 45, 27-37. https://doi.org/10.1097/AIA.0b013e318034194e 